\title{
Conflitos identitários do sujeito pós-moderno em O Homem Duplicado
}

\author{
Identity conflicts of the subject post-modern in O Homem Duplicado
}

\author{
Thaíla Moura Cabral ${ }^{*}$ \\ Universidade Estadual de Feira de Santana \\ Feira de Santana, Bahia, Brasil \\ Tércia Costa Valverde** \\ Universidade Estadual de Feira de Santana \\ Feira de Santana, Bahia, Brasil
}

Resumo: No presente estudo, apresentaremos alguns reflexos da Pós-Modernidade na arte literária portuguesa, destacando a crise existencial do sujeito. Para tal, será aludido como exemplo a narrativa ficcional de José Saramago, O bomem duplicado (2002), trama esta, na qual o autor se debruça sobre a qualidade de vida e a situação do homem contemporâneo, imerso em crise, quando depara-se com outras identidades incompatíveis com a sua. Para a concretização do trabalho, lançaremos mão dos estudos de teóricos que discorrem sobre assuntos presentes na Pós-Modernidade, como Zygmunt Bauman (2005) e Anthony Giddens (2002). O âmbito crítico da escrita saramaguiana receberá apoio da obra da estudiosa Ana Paula Arnaut (2008), como também de Carlos Reis (2008), que auxiliarão na visão da perspectiva singular dos temas abordados pelo escritor. Desse modo, $O$ homem duplicado nos levará a uma reflexão crítica no que diz respeito à questão identitária: Que o encontro do sujeito na busca de si perpassa pelo encontro com o outro.

Palavras-chave: Literatura Portuguesa. José Saramago. O homem duplicado. Crise de identidade.

Abstract: In this study, we present some reflections of Post-Modernity in portuguese literary art, highlighting the existential crisis of the subject. This will alluded to the example of the fictional narrative of José Saramago, O bomem duplicado (2002), plot this, in which the author focuses on the quality of life and condition of the contemporary man, immersed in an identity crisis when it faces with other identities incompatible with yours. In carrying out the work, we will launch hand of theoretical studies that discuss present issues in Post-Modernity as Zygmunt Bauman (2005) and Anthony Giddens (2002). The critical part of Saramago receive written support of the work of scholar Ana Paula Arnaut, as well as Carlos Reis, which will help in view of the unique perspective of the issues addressed by the writer. Thus, O bomem duplicado, will lead us to a critical reflection with regard to identity issue: The subject of the meeting in search of itself, moves through the encounter with the other.

Keywords: Portuguese Literature. José Saramago. O homem duplicado. Identity crisis

*Mestranda do Programa de Pós-Graduação em Estudos Literários - PROGEL - Universidade Estadual de Feira de Santana, Feira de Santana, Bahia, Brasil. E-mail: thaila.mouracabral@gmail.com.

** Professora do Programa de Pós-Graduação em Estudos Literários - PROGEL - Universidade Estadual de Feira de Santana, Feira de Santana, Bahia, Brasil. E-mail: tecaverde05@outlook.com. 


\section{A CRISE DO SUJEITO PÓS-MODERNO EM O HOMEM DUPLICADO}

Neste artigo, traremos como objeto de estudo a obra ficcional do escritor lusitano José Saramago, O bomem duplicado (2002), salientando algumas representações da PósModernidade na Literatura, com destaque para a crise identitária do sujeito. No romance em estudo, o autor se volta para a qualidade e a situação do homem contemporâneo: Imerso em uma crise de identidade, quando depara-se com outras identidades incompatíveis com a sua.

O próprio José Saramago denominou Ensaio sobre a cegueira (1995), Todos os nomes (1997) e A caverna (2000) como uma "[...] 'trilogia involuntária' na base do mesmo caráter alegórico, pessimista e desencantado de romances sobre um mundo abandonado pela razão." (SARAMAGO apud LOPES, 2010, p. 158). É a partir daí, do ano 1995, que começa o segundo ciclo da produção literária do escritor: "Passei a tratar de assuntos sérios de uma forma abstracta [sic]: considerar um determinado tema mas despindo-o de toda circunstância social, imediata, histórica, local." (SARAMAGO apud AGUILERA, 2008, p. 118-119). Conforme Ana Paula Arnaut (2008, p. 40) esclarece:

Estes [referentes aos romances citados acima e aos posteriores a eles], [...] apontam para uma vertente crítica de maior abrangência histórico-social (não falamos, neste caso, de romances históricos mas não podemos esquecer que, de uma maneira ou de outra, todo o romance evidência estreitas ligações com a realidade que lhe dá origem).

Com isso, as obras saramaguianas passam a destilar uma maior universalidade dos temas: deixando de lado aspectos do discurso histórico de Portugal atrelado à ficção (traço encontrado, por exemplo, em Memorial do convento - 1982), para dar espaço a assuntos que abarcam leitores das mais diversas latitudes. Nas palavras de Arnaut (2008, p. 47), veem-se que:

O que estes últimos romances comprovam, afinal, é um diferente tipo de interesse, e também de abordagem, em relação à sociedade e ao mundo em que vivemos. Um mundo, e não apenas um país, Portugal, onde os valores podem deixar de fazer sentido e onde o Homem pode deixar de saber quem é.

O perigo de crise existencial abordado por Arnaut (2008), em José Saramago, ocorre também com as personagens em $O$ homem duplicado (2002). Romance dividido em dezoito partes, sem numeração capitular, narrado em terceira pessoa, sem referência a tempo, lugar e publicado no ano de 2002, apresenta um enredo que leva o leitor a reflexões significativas quanto ao caos identitário e às relações com o outro na vida do homem pós-moderno.

No enredo do livro em estudo, Saramago traz uma trama envolvida por conflitos de identidade e alteridade, sobre os meandros da condição humana. No romance, encontramos o professor de História Tertuliano Máximo Afonso. O nome "Tertuliano" nos remete à "tertúlia", reunião entre amigos para discutir Literatura, significado totalmente oposto à personalidade do professor, haja vista que é um sujeito de poucos 
amigos e poucas relações sociais. Podemos nos referir, também, à característica de metalinguagem narrativa: Tertuliano/tertúlia/literatura, assim como a reflexão sobre a disciplina de História, que está presente no texto literário em análise, uma vez que, como mencionado por Linda Hutcheon (1991, p. 141), Literatura e História já foram consideradas da mesma árvore do conhecimento. Já "Máximo", nos reporta à ideia de grandeza, e ainda, "Afonso", também nome de grandes reis e governantes, como D. Afonso Henriques (1109-1185), rei de Portugal. Significados esses, em relação aos nomes do protagonista, que podem nos levar a falsas pistas quanto à personalidade do referido professor. Contudo, Tertuliano é "Máximo" e, de certa forma, corresponde a um de seus nomes, pois será no fim da narrativa, o sobrevivente entre suas cópias.

A obra ficcional em estudo apresenta como personagem central o já mencionado professor de História, além de outras pessoas envolvidas no enredo. Maria da Paz, que é amiga/namorada/amante de Tertuliano; o ator secundário António Claro, de codinome Daniel Santa-Clara; e Helena, a esposa de Claro. Como também outras figuras: O professor de Matemática, o senso comum (uma espécie de consciência de Tertuliano), Carolina (mãe de Tertuliano Máximo Afonso), além da presença de Tomarctus, o cachorro. De repente, ao ver um filme em sua casa, o protagonista percebe que um dos atores é fisicamente igual a si, ou seja, seu sósia. A partir daí, começa uma busca investigativa para descobrir quem era o tal ator. O recurso da ironia é outra recorrência na ficção saramaguiana. No romance em estudo não é diferente.

"O caos é uma ordem por decifrar". Com esta epígrafe, o autor português direciona o leitor para as desordens que o sujeito pós-moderno está imerso: Envolto em angústia e desprezo pelo outro. O livro em estudo é visto como pertencente ao segundo ciclo das obras de Saramago, diferente da primeira fase saramaguiana, que se volta para a história de Portugal. Já o segundo ciclo, corrobora fortes ligações com a realidade a qual lhe originou, o mundo, não mais apenas aquele país europeu que viveu períodos de glórias e de quedas em sua epopeia lusitana.

Tertuliano vive uma vida dita normal. Divorciado há seis anos, dá aulas em uma escola de ensino secundário. Não é dado a saídas noturnas ou a outros tipos de distração que não seja a leitura de livros. Dedica-se, exclusivamente, às atividades escolares. Sua vida beira a depressão, uma vez que carece de entusiasmo para enfrentar a realidade. O caos em sua existência tem o ponto inicial quando recebe, como sugestão do colega professor de Matemática, a apreciação do filme "Quem Porfia Mata Caça":

[...] Não me lembro de que alguma vez tenhamos falado de cinema, mas agora digo-lhe, meu caro, tem de ver, é indispensável que veja Quem Porfia Mata Caça, [...].

[...] Tertuliano Máximo Afonso levantou-se da cadeira, ajoelhou-se diante do televisor, a cara tão perto do ecrã quanto lho permitia a visão, Sou eu, disse, e outra vez sentiu que se lhe eriçavam os pêlos [sic] do corpo, o que ali estava não era verdade, não podia ser verdade, [...]. (SARAMAGO, 2008, p. 10-20).

“Quem Porfia Mata Caça”, é um provérbio português que significa dizer que quem 
persiste em conseguir algo, em algum momento, atingirá seu objetivo. Depois de assistir ao filme, o professor de História inicia um verdadeiro ato de investigação para descobrir quem é o seu sósia. Por se tratar de um ator secundário, o nome dele não aparece nos créditos do filme associado à personagem interpretada. Tertuliano decide então, como ação inicial, alugar outros filmes produzidos pela mesma produtora de "Quem Porfia Mata Caça". O interesse exclusivo por películas daquela produtora, no mínimo, desperta curiosidade ao funcionário da locadora, ao que o docente diz tratar-se de "[...] um estudo sobre as tendências, as inclinações, os propósitos, as mensagens, tanto as explícitas como as implícitas e subliminares, em suma, os sinais ideológicos que uma determinada empresa produtora de cinema [...]." (SARAMAGO, 2008, p. 44), desculpa falsa, que, confuso e aturdido, Máximo Afonso inventou.

Paradoxalmente, em contraponto a outras narrativas de Saramago, a exemplo do Conto da ilha desconbecida (1998) e Ensaio sobre a cegueira (1998), em que os personagens são conhecidos por suas profissões ou características, mas que são figuras com personalidades fortes e seguras, em O homem duplicado, apesar do professor de História Tertuliano Máximo Afonso ser colocado sempre em sua forma completa, sua identidade é fragmentada e caótica: Não sabe o que e quem é; não consegue manter laços afetivos fortes e seguros; vive envolto em incertezas e angústias quanto à formação de seu próprio eu.

O senso comum também entra como personagem do enredo, configurando-se como uma espécie de consciência do homem duplicado. Um de seus conselhos é de que deixe de lado a ideia fixa de ir à busca de um indivíduo que é a sua cópia, ou vice-versa. Isso ocorre na tentativa de evitar ações pelas quais acarretem graves resultados, em que Tertuliano venha a se arrepender posteriormente:

[Senso comum] [...] larga-a se não queres que te queime, devolve o vídeo à loja hoje mesmo, pões uma pedra sobre o assunto e acabas com o mistério antes que ele comece a deitar cá para fora coisas que preferirias não saber, ou ver, ou fazer, além disso, supondo que há uma pessoa que é uma cópia tua, ou tu uma cópia sua, e pelos vistos há mesmo, não tens nenhuma obrigação de ir à procura dela. (SARAMAGO, 2008, p. 26-27).

Tertuliano não atendeu aos conselhos de sua consciência, preferiu seguir o senso investigativo e curioso da natureza humana, que o levará a caminhos nada prometedores. Todos os diálogos realizados por eles, senso comum e o professor, acontecem silenciosamente, no nível do pensamento, travando uma relação binomial de irracionalidade e racionalidade; dúvidas e certezas, funcionando como um combate entre Tertuliano e seu Eu: “[...] estamos obrigados por natureza ou condição a seguir caminhos paralelos, mas a distância que nos separa, ou divide, é tão grande que na maior parte dos casos não nos ouvimos um ao outro [...]." (SARAMAGO, 2008, p. 27), diz o senso comum. É como se este, senso comum, funcionasse como uma espécie de voz que tenta trazer consciência para a mente caótica do professor.

A ilegitimidade e insegurança identitárias que o professor de História passa a galgar, desde a inexplicável descoberta, não afeta de modo tão extremo, ao menos de princípio, 
o ator António Claro. Exceto quando seu ego é ferido por Tertuliano, daí seu maucaratismo surge e transporta a si, como também outras figuras do romance, ao fim trágico.

Maria da Paz, a amiga/namorada/amante do personagem central do livro, tem um relacionamento indefinido com este. A moça transborda sentimentos e perspectivas de futuro que não são projetados da mesma forma por Máximo Afonso. Ele a tem como uma "amiga" que cede ao papel de namorada/amante ocasionalmente:

\begin{abstract}
Depois de muito puxar pela cabeça, Tertuliano Máximo Afonso achou que, para maior segurança, o mais prudente seria escrever a mensagem e lê-la para o telefone. Eis o que lhe saiu depois de alguns papéis rasgados, Maria da Paz, cá ouvi as tuas mensagens, e o que tenho para te dizer é que devemos agir com calma, tomar as decisões certas para um e para outro, sabendo que a única coisa que dura toda a vida é a vida, o resto é sempre precário, instável, fugidio, a mim o tempo já me ensinou esta grande verdade, mas uma coisa tenho por certa, que somos amigos e amigos vamos continuar a ser, o que necessitamos é de uma longa conversa, então já verás como tudo se resolverá pelo melhor, telefono-te um destes dias. Hesitou um segundo, o que ia a dizer não estava escrito, e terminou, Um beijo. (SARAMAGO, 2008, p. 60-61).
\end{abstract}

Precário e fugidio. Eis o caráter do perfil da relação entre os dois. Situação que incomoda a bancária (profissão de Maria da Paz), mas que se espaça por um longo período do romance, uma vez que ela tem receio de perder, integralmente, o enamorado. Assim, com toda paciência, entretanto, sem deixar de transparecer seu sofrimento diante da decepção, ao ser deixada de lado muitas vezes por Tertuliano, Maria da Paz conduz seu fragmentado relacionamento com o professor.

O fato de Tertuliano não conseguir empreitar um relacionamento pautado em uma determinada solidez e segurança, que gere um "futuro" com Maria da Paz, é uma característica recorrente na condição dos indivíduos pós-modernos: Não sabemos mais manter laços a longo prazo. Mediante os apontamentos de Zygmunt Bauman (2005, p. 69), isto se configura como um medo do desconhecido, ou seja, do futuro.

A problemática existencial que conduz $O$ homem duplicado se desenvolve a partir do questionamento: “Quem sou eu exatamente?”. É na descoberta da existência de um corpo tal qual o seu, entretanto, quanto à personalidade, ainda não se tem notícia. A sua individualidade entra em risco: Até que ponto nossa personagem central é o que é, e gosta do que gosta? São dúvidas e indagações que começam a surgir na cabeça de Tertuliano Máximo Afonso: “[...] às vezes tenho até a impressão de não saber exactamente [sic] o que sou, sei quem sou, mas não o que sou [...]." (SARAMAGO, 2008, p. 58). Nos levando a refletir o quanto o âmbito identitário se legitima como um fator de arestas polivalentes e escorregadias na condição pós-moderna. Estamos cada vez mais incertos quanto ao que somos e quem somos. Carlos Reis (2008, p. 189) nos diz:

O Homem Duplicado de forma sombria parece sugerir é a dificuldade de uma vivência harmoniosa dessa autognose em diálogo de alteridade por aqueles que são mais do que 
semelhantes: [grifo do autor] a plena e radical igualdade vivida por Tertuliano Máximo Afonso e António Claro - metáfora e hipérbole da anulação das diferenças entre homens acaba por se resolver em aniquilação do outro.

Não há espaço para o outro, não há acordo, tanto na narrativa de Saramago quanto no contexto pós-moderno. Para que um afirme sua individualidade, o outro precisa deixar de existir. É o que ocorreu em O homem duplicado. António Claro morre em um acidente automobilístico, e o professor assume a identidade do ator. Oficialmente, quem estava conduzindo o carro era Tertuliano Máximo Afonso, que, para todos os efeitos, depois da tragédia, encontra-se morto. Nas linhas finais do romance, o agora António Claro recebe uma ligação de um outro duplicado. Ironicamente o script volta a se repetir. O duplicado pensa em levar o roteiro para as últimas consequências:

O telefone tocou. Sem pensar que poderia ser algum dos seus novos pais ou irmãos, Tertuliano Máximo Afonso levantou o auscultador e disse, Estou. Do outro lado uma voz igual à sua exclamou, Até que enfim. Tertuliano Máximo Afonso estremeceu, nesta mesma cadeira deveria ter estado sentado António Claro na noite em que lhe telefonou. Agora a conversação vai repetir-se, o tempo arrependeu-se e voltou para trás. É o senhor Daniel Santa-Clara, perguntou a voz, Sim, sou eu, Andava há semanas à sua procura, mas finalmente encontrei-o, Que deseja, Gostaria de me encontrar pessoalmente consigo, Para quê, Deve ter reparado que as nossas vozes são iguais, Parece-me notar uma certa semelhança, Semelhança, não, igualdade, [...]. Depois foi ao quarto, abriu a gaveta onde estava a pistola. Introduziu o carregador na coronha e transferiu um cartucho para a câmara. Mudou de roupa, camisa lavada, gravata, calças, casaco, os sapatos melhores. Entalou a pistola no cinto e saiu. (SARAMAGO, 2008, p. 283-284).

É no momento descrito no excerto acima, que Tertuliano, com a identidade de António Claro assumida, pega uma arma e arruma-se no intuito de matar o homem que diz ser seu semelhante ou igual. Diante do exposto, fica a ideia de que não há lugar para a alteridade e, a confirmação da insegurança do "Eu" perante à ameaça identitária do "Outro". Segundo Antony Giddens (2002, p. 54), a ordem do cotidiano da vida é sólida e constante, contudo, "o mais leve olhar de uma pessoa a outra, a inflexão da voz, a mudança da expressão facial ou gestos do corpo podem ameaçá-la [...].”. É essa ordem apontada por Giddens (2002, p. 54) que Tertuliano percebe em ameaça com a descoberta de um outro igual, nas cenas do filme visto, e depois com o telefonema nas páginas finais do livro: A voz, a face e os gestos de um outro "Eu" são perturbadoras e comprometerão sua vida diária.

Para compreensão do dilema identitário do sujeito na Pós-Modernidade, faz-se necessário considerar alguns personagens de forma mais detida e, para isso, foi escolhida a figura central do enredo saramaguiano em estudo, Tertuliano Máximo Afonso, bem como sua relação conflituosa com Maria da Paz, assuntos que serão discorridos nos próximos tópicos do presente trabalho. 


\title{
2.1 O HOMEM DUPLICADO: TERTULIANO MÁXIMO AFONSO E O SEU CONFLITO IDENTITÁRIO
}

Tertuliano é um homem deprimido, enclausurado em si. Sua vida se limita ao trabalho na escola e leituras a respeito de assuntos direcionados à sua profissão. Seu relacionamento com Maria da Paz se constitui quase que como uma obrigação, ao invés de escolha e do gostar propriamente dito. Sua mãe Carolina, longe da percepção dela, é quase um fardo que carrega: Lembrar de fazer um telefonema de tempos em tempos para ela e passar alguns dias do período de férias na casa em que cresceu são ações fastigiosas para o nosso caro professor de História. Ironicamente, nas primeiras vinte páginas do romance, o narrador atribui a Máximo Afonso características físicas de um ator galã:

\begin{abstract}
Não se trata de proclamar aqui que Tertuliano Máximo Afonso é uma perfeita figura de homem, a tanto não lhe chegaria a imodéstia nem a nós a subjectividade [sic], mas, tivesse ele ao menos uma pitada de talento que sem dúvida poderia fazer uma excelente carreira no teatro interpretando papéis de galã. E quem diz teatro, diz cinema, claro está. Um parêntesis indispensável. (SARAMAGO, 2008, p. 29).
\end{abstract}

Ironicamente, porque o seu igual é um ator, isto é, Tertuliano apresenta algumas características para tal tipo de profissional, contudo, não tem habilidade para atuação, diferentemente de seu sósia António Claro. A vida monótona de Tertuliano Máximo Afonso é completamente alterada depois do descobrimento da existência desse sósia. Apesar de sua aparente sensatez e temperamento metódico, a curiosidade do professor de História se sobressai. Começa, então, a buscar o ator António Claro, contudo, por este utilizar o pseudônimo de Daniel Santa-Clara, encontra certas dificuldades para conseguir o endereço de Claro. É através de carta enviada à produtora cinematográfica que o nome verdadeiro do ator, assim como o local da residência, são descobertos por Tertuliano.

Máximo Afonso, antes da descoberta de seu igual, praticamente não vivia. Existia no limiar da depressão, em uma rotina envolvida por marasmo e apatia. Não dava importância às relações sociais, nem tão pouco ao relacionamento com Maria da Paz. É a partir da descoberta de António Claro, que sua existência passa a ser percebida por si mesmo, por meio da igualdade física do outro, que ele começa, então, buscar o seu Eu, ou outro Eu.

O ser humano é passível de crise. Ainda mais quando se trata da relação entre nossa existência e a do outro. A zona de conflito vivida por nosso protagonista, evidencia seu precário devir existencial, em outros termos, passar pelos processos de mudanças, que são naturais na vida do ser humano, é extremamente conflituoso para Máximo Afonso. Tertuliano se percebe um professor medíocre, com pouco talento para a docência. Tem a ideia de revolucionar o ensino da História, mas, ao mesmo tempo, não apresenta resistência e capacidade de sustentar seu ponto de vista perante a comunidade escolar. Sua opinião é de que a História deveria ser ensinada da contemporaneidade para o passado e 
não o inverso. Observemos o excerto abaixo:

\begin{abstract}
Depois do almoço, Tertuliano Máximo Afonso participou, com a maior parte dos seus colegas, numa reunião que havia sido convocada pelo diretor [sic] a fim de ser analisada a última proposta de actualização [sic] pedagógica emanada do ministério, [...]. Quando chegou a sua vez de falar, num tom indolente e monocórdico que os presentes estranharam, limitouse a repetir uma ideia que ali deixara já de ser novidade e que era motivo invariável de alguns risinhos complacentes do plenário e de mal disfarçada contrariedade do diretor [sic], Em minha opinião, disse ele, a única opção importante, a única decisão séria que será necessário tomar no que respeita ao conhecimento da História, é se deveremos ensiná-la de trás para diante ou, segundo a minha opinião, de diante para trás, todo o mais, não sendo despiciendo, está condicionado pela escolha que se fizer, toda a gente sabe que assim é, mas continua a fazer-se de conta que não. Os efeitos da perorata foram os de sempre, suspiro de mal resignada paciência do diretor [sic], trocas de olhares e murmúrios entre os professores. (SARAMAGO, 2008, p. 40-41).
\end{abstract}

Com isso, observamos a fraqueza do professor ao expor suas ideias: Com um tom de voz desleixado, indolente, sem ritmo. Ou seja, apesar de sua convicção quanto às mudanças que os rumos do ensino da História deveriam tomar, não consegue imprimir eloquência e argumentar de modo a convencer os colegas de trabalho. Prefere usar a passividade a enfrentar e encorajar a si e aos outros professores, um processo de transformação pedagógica.

Após conseguir contato com seu igual, o ponto conflituoso de Máximo Afonso, a identidade, é ainda mais acentuado. Apesar da relutância inicial, António Claro aceita a proposta do professor e vai ao seu encontro reservado, em uma espécie de casa de campo do ator. Ao se perceberem um diante do outro, é como se fossem um espelho: Um a imagem fiel do outro. Vejamos:

As mãos eram em tudo iguais, cada veia, cada ruga, cada pêlo [sic], as unhas uma por uma, tudo se repetia como se tivesse saído de um molde. [...] a prova está mais do que feita, mãos, braços, caras, vozes, tudo em nós é igual, só faltaria que nos despíssemos por completo. (SARAMAGO, 2008, p. 191).

Logo no mencionado primeiro encontro, surgem indagações: Quem é a cópia de quem? Quem nasceu primeiro? Quem é o duplicado de quem? Descobre-se que o duplicado é Tertuliano Máximo Afonso. Este nasceu meia hora depois que António Claro. Contudo, o narrador é sutil ao traçar o perfil do ator. Não há evidências contundentes de que realmente não houve mentiras ao dizer o horário exato do nascimento de Claro:

[...] poderemos tirar à sorte aquele a quem caberá falar em primeiro lugar, Não é preciso, eu começo, você mesmo referiu que é uma questão de rectidão [sic] e boa-fé, disse Tertuliano Máximo Afonso, Nasceu então a que horas, Às duas da tarde. António Claro pôs uma cara 
de pena e disse, Eu nasci meia hora antes, ou, para falar com absoluta exactidão [sic] cronométrica, pus a cabeça de fora às treze horas e vinte e nove minutos, lamento-o, meu caro, mas eu já cá estava quando você nasceu, o duplicado é você. (SARAMAGO, 2008, p. 194-195).

Aceitar o outro como semelhante, como igual, mais ainda, ser "o homem duplicado”, estremece as bases identitárias de Tertuliano. Segundo Bauman (2005, p. 38), esse processo ansioso por uma identidade, ou identidades, em nossa existência líquidamoderna, provavelmente, é um dos aspectos mais perturbadores e ambivalentes. Em outras palavras, busca-se a segurança de uma identificação, ao passo que, quando se encontra a tal identidade, ela é negada. A identificação, principalmente com o outro, não é aceita. Isto é, ao mesmo tempo que se almeja identificar-se, deseja-se a particularidade de ser único.

O encontro entre os dois homens iguais acontece fora da cidade onde moram. É como se a metrópole "engolisse" Tertuliano Máximo Afonso de tal maneira, que o impedia de enxergar sua existência. Assim, o professor e o ator têm o primeiro contato físico em um local afastado, longe de tudo. Com isso, metaforicamente, para Tertuliano enxergar a si, foi preciso ver o outro fora do ambiente rotineiro.

Seguindo esta linha de metáforas, tão recorrente no cabedal de obras de José Saramago, podemos aludir ao romance $A$ caverna (2000), alegoria saramaguiana do "Mito da caverna", do filósofo grego Platão. No mito, para o sujeito sair da escuridão foi preciso sair da caverna, mas, na alegoria de Saramago, o indivíduo precisou entrar na caverna (o Centro [cidade]) para perceber as correntes pelas quais estava preso. Já em $O$ homem duplicado, o personagem central precisou sair da cidade [caverna] para seguir o trajeto incessante de busca identitária, reforçando o intertexto com a obra platônica.

Depois da conversa presencial entre os dois homens iguais, António Claro busca descobrir como o professor de História chegou até ele. Já era sabido que foi através de uma carta enviada a produtora cinematográfica, que Máximo Afonso descobriu o verdadeiro nome e endereço do ator, contudo, o tal escrito não foi assinado pelo homem duplicado, mas, sim, por uma mulher, Maria da Paz. É válido destacar que a carta foi enviada com o consentimento de Da Paz, entretanto, sem o conhecimento real do conteúdo epistolar.

Helena, esposa de Claro, ficou altamente perturbada com todos esses novos acontecimentos que passaram a transformar a vida do casal. Fato que António Claro utiliza como argumento para tramar uma espécie de "vingança maliciosa". Ele propõe que o professor de História troque de lugar com ele por uma noite, caso contrário, tudo que até então foi escondido da bancária, seria exposto a ela. Tertuliano vê-se diante de uma faca de dois gumes: Aceitar que outro homem durma com sua namorada, ou contar-lhe toda a verdade. Nosso personagem é hesitante. Prefere a fraqueza e a comodidade da mentira, à coragem e sensatez de assumir a verdade.

Tudo é planejado para que os dois homens troquem de lugar por uma noite. Tudo corre como o combinado. Helena, apesar de algumas estranhezas, não percebe que não está realmente diante de seu marido, nem tão pouco Maria da Paz nota que não está com 
o namorado. Todavia, chega a manhã do dia seguinte. Um aspecto chama atenção de Da Paz: A marca esbranquiçada da aliança no dedo do seu suposto namorado:

\begin{abstract}
Pouco a pouco, como quem vai procurando e descobrindo as peças certas para o pu₹žle [grifo nosso], começou a relacionar acontecimentos e acções [sic], recordou palavras equívocas que havia escutado a Tertuliano Máximo Afonso, as suas evasivas, a carta recebida da produtora de cinema, a promessa que ele fizera de que um dia lhe contaria tudo. Não podia ir mais longe, continuaria a não saber quem era este homem, salvo se ele próprio o dissesse. A voz de Tertuliano Máximo Afonso ouviu-se lá de dentro, Maria da Paz. [...] Quem é você, perguntou Maria da Paz, e antes que ele respondesse, De que anel é a marca que tem no dedo. António Claro olhou a mão e disse, Ah, isto, Sim, isso, você não é o Tertuliano, Não sou, de facto não sou o Tertuliano, Quem é, então, Por agora, contenta-te com saber quem não sou, mas quando estiveres com o teu amigo podes perguntar-lhe, Perguntarei, preciso de saber por quem fui enganada, Por mim, em primeiro lugar, mas ele ajudou, ou melhor, o pobre homem não teve outro remédio, o teu noivo não o teu noivo não é propriamente um herói. (SARAMAGO, 2008, p. 280-281).
\end{abstract}

O acontecimento leva Maria da Paz e António Claro, este com a identidade de Tertuliano, a um fim trágico. Os dois morrem em um acidente automobilístico, depois de saírem em plena discussão da casa de campo do ator. Por ironia, com a morte factual de António Claro, quem assume sua identidade por definitivo, é o seu igual, o homem duplicado, Tertuliano Máximo Afonso. O professor de História, agora, teoricamente morto, torna-se o ator secundário de cinema Daniel Santa-Clara e passa a viver com Helena.

\title{
1.2 Tertuliano e a relação conflituosa de alteridade com Maria da Paz
}

Maria da Paz é uma jovem mulher com atributos de beleza física. Mora com sua mãe e trabalha em uma instituição financeira. Seu relacionamento com Tertuliano é um tanto quanto complexo, pois as perspectivas de futuro para ambos são incongruentes. Ela almeja um futuro que Máximo Afonso esteja incluído, mas ele não tem a mesma visão que a moça. Apesar de se mostrar inconformada com a falta de segurança e estabilidade no namoro, pouco pressiona o namorado, haja vista que o medo de o perder por completo é maior. Conforme os apontamentos de Zygmunt Bauman (2005, p. 99), esse é um dos grandes medos do ser humano, o desprezo:

O que todos nós parecemos temer, quer estejamos ou não sofrendo de "depressão dependente", seja à luz do dia ou assombrados por alucinações noturnas, é o abandono, a exclusão, ser rejeitado, ser banido, ser repudiado, descartado, despido daquilo que se é, não ter permissão de ser o que se deseja ser. Temos medo de nos deixarem sozinhos, indefesos e infelizes. Tememos que nos neguem companhia, corações amorosos, mãos amigas. 
Receamos ser atirados ao deposito de sucatas.

E é por este prisma que o enredo da bancária é construído, traçado pelo receio de ficar sozinha. Tertuliano Máximo Afonso tem sua existência em meio ao caos. Maria da Paz, em uma análise lúcida da vida do namorado, discorre sobre a ordem que o caos pode apontar. Vejamos no trecho a seguir:

O caos é uma ordem por decifrar, Quê, que foi que disseste, perguntou Tertuliano Máximo Afonso, que já tinha a lista dos nomes a salvo, Que o caos é uma ordem por decifrar, Onde foi que leste isso, a quem o ouviste, Ocorreu-me neste momento, não creio que o tivesse lido alguma vez, e, ouvi-lo a alguém, isso tenho a certeza de que não, Mas como foi que te saiu uma frase dessas, Que tem de especial a frase, Tem muito, Não sei, talvez fosse porque o meu trabalho no banco se faz com algarismos, e os algarismos, quando se apresentam misturados, confundidos, podem aparecer como elementos caóticos a quem os não conheça, no entanto existe neles, latente, uma ordem, na verdade creio que os algarismos não têm sentido fora de uma qualquer ordem que se lhes dê, o problema está em saber encontrá-la, Aqui não há algarismos, Mas há um caos, foste tu mesmo que o disseste [...]. (SARAMAGO, 2008, p. 90).

Assim, o diálogo entre a bancária e o professor, acima citado, confirma a ideia da personagem feminina como ponto de partida para o olhar reflexivo sobre a lucidez, presente na escrita literária de José Saramago. Maria da Paz, ao provocar reflexão em Tertuliano, ao falar sobre o caos que busca decifrar a ordem em sua vida, leva a pensar sobre o âmbito do autoconhecimento do ser humano, que passa também pelo perceber o outro. Pode-se inferir, ainda, a personagem da Paz como álter ego de Saramago. Uma vez que o autor nos leva, por meio de uma visão altamente lúcida, às suas narrativas, a observarmos a crise identitária em que a humanidade está imersa.

E esse perceber o outro é que não está, digamos, desenvolvido na personalidade de Máximo Afonso. Isto, na medida em que seja o relacionamento com da Paz, ou até mesmo os laços familiares com sua mãe Carolina não se constituem como peças fundamentais no curso de sua vida. É um homem ensimesmado, perplexo diante dos "[...] labirintos cretenses que são as relações humanas.” (SARAMAGO, 2008, p. 181), em outras palavras, assim como os labirintos da ilha grega Creta, as relações entre os seres humanos são complexas, difíceis de percorrer. E tornar seu "namoro" com Maria da Paz em algo alicerçado é enveredar por caminhos que aparentam ser temerosos na percepção do professor. Sobre este aspecto, Bauman (2005, p. 69) esclarece:

Amar significa estar determinado a compartilhar duas biografias, cada qual portando uma carga diferente de experiências e recordação, e cada qual seguindo seu próprio rumo. Justamente por isso, significa um acordo sobre o futuro e, portanto, sobre um grande desconhecido [grifo do autor]. 
Esse "acordo sobre o futuro", mencionado por Bauman (2005, p. 69), é o grande medo de Tertuliano e o desejado sonho matrimonial de Maria da Paz. O professor tentou, por diversas vezes, colocar um ponto final na relação, contudo, sua covardia e, (por que não, medo de ficar só?), não permitiram que isso acontecesse. É tarde demais quando Máximo se dá conta do grau de importância que a bancária representava em sua vida. Tal fato só ocorreu pouco tempo antes da morte de Da Paz. Sobre o unir duas biografias diferentes, ao qual Bauman (2005, p. 69) se refere, é percebido um pensar a respeito do assunto pelo professor de História já nos capítulos finais do romance:

\begin{abstract}
Decidiu que irá viver com ela e aí se tem mantido firme, e se a resolução ainda não foi concretizada, ou levada à prática, como também usualmente se diz, é porque passar da palavra ao acto [sic] tem igualmente os seus quês, os seus rabos por esfolar, é indispensável, por exemplo, que o espírito se arme de forças bastantes para empurrar o indolente corpo ao cumprimento do dever, sem falar dos prosaicos assuntos de logística que não podem resolver-se assim do pé para a mão, como saber-se quem irá viver para casa de quem, se Maria da Paz para a pequena casa do amado, se Tertuliano Máximo Afonso para casa mais ampla da amada. (SARAMAGO, 2008, p. 243).
\end{abstract}

Porém, o maquiavélico plano, de António Claro de ocupar o lugar do professor de História por uma noite junto a Maria da Paz, é bem-sucedido, no sentido de que Máximo Afonso não tem coragem suficiente para contar toda a verdade a sua amada, no que concerne a existência de um homem igual a si. Nisso, como já aludido anteriormente, sua amada é morta em um trágico acidente de carro. Logo, podemos inferir que Tertuliano precisava da amada para realizar o que não tinha coragem de fazer sozinho (como a aproximação primária com seu sósia), ao tempo que foi preciso a presença inoportuna de Claro para que notasse o quanto a amada o fazia pleno e lhe era importante.

A relação de Tertuliano com sua mãe, Carolina, também é mantida a distância, com ressalvas. Ela não reside na mesma cidade que o professor. Viúva, mora apenas com o cachorro Tomarctus. O filho somente de tempos em tempos, lembra de lhe dirigir um telefonema, isso por obrigação. Nas férias, designa alguns poucos dias para visitar a genitora:

[...] Quando será que o meu filho me telefona, e eis que de repente tem a sua voz juntinha ao ouvido, Bons dias, minha senhora mãe, [...] E essas aulas, quando é que acabam este ano, Daqui por duas semanas, [...] Quer dizer que antes de um mês estarás aqui comigo, Irei vêla, claro, mas não poderei ficar mais que três ou quatro dias, Porquê, É que tenho ainda umas coisas para arrumar aqui, umas voltas a dar [...]. (SARAMAGO, 2008, p. 120).

Esta visita, acima referida, só ocorre no ápice da crise vivida por nosso protagonista. Já na viagem para a casa da mãe, Tertuliano pondera entre contar ou não contar a Carolina tudo o que vem se passando a respeito da descoberta de um homem igual a si. Decidiu 
por contar. Decisão acertada, pois é a mãe a quem recorrerá depois do acidente de carro em que, supostamente, ele era uma das vítimas fatais.

Então, ainda que o professor não desse a devida importância à sua mãe, é aquela mulher que representará o fator segurança na vida daquele homem. Assim como no Conto da ilha desconbecida (1998), em que a mulher da limpeza representava a fortaleza do homem diante dos obstáculos na busca pelo desconhecido, Carolina é a fortaleza de Tertuliano Máximo Afonso. Desse modo, em condições de dúvidas e precariedades, para o indivíduo encontrar confiança significa possuir senso de segurança. Anthony Giddens (2002, p. 11) relata que:

Em circunstâncias de incerteza e múltipla escolha, as noções de confiança e risco têm aplicação particular. A confiança, afirmo, é um fenômeno genérico crucial do desenvolvimento da personalidade e tem relevância distintiva e específica para o mundo de mecanismos de desencaixe e de sistemas abstratos. [...] gera aquele "salto de fé" que o envolvimento prático demanda.

Tal confiança e segurança, o protagonista encontrará na pessoa de Carolina, sua mãe. É ela quem o ajudará nas primeiras dificuldades depois da morte de seu igual, no acidente de automóvel. Corroborando também, a figura feminina como ponto crucial nos enredos saramaguianos.

Com Maria da Paz morta, Tertuliano Máximo Afonso, em tese, morto também, por ironia, o professor de História, que no início do romance é comparado a um galã de cinema, assume uma nova identidade, ou apenas seu outro "Eu". Toma posse da profissão, da esposa e da identidade de seu igual: o ator coadjuvante António Claro. O desafio, agora, é saber lidar, literalmente, com essa identidade multifacetada. Sem contar, com o insólito que surge no fim do enredo: Um outro duplicado, ou seja, "o homem triplicado".

Com isso, José Saramago nos leva a refletir que o ser humano é múltiplo em identidades: Ao abordar a duplicação do homem, para além de que uma visão materialista e biológica poderiam alcançar. $\mathrm{O}$ que nos faz pensar o quanto a arte literária nos leva a transpor as limitações da razão, como bem aponta Valverde (2014, p. 34): "Quando nem a razão e nem a ciência conseguem ofertar respostas ao homem, eis que a literatura, veículo por excelência do mito, aparece para amenizar as dores humanas.". Desta maneira, esta narrativa ficcional em análise, nos atrai ao olhar crítico sobre a representatividade da identidade do ser humano, nos distanciando e, ao mesmo tempo, aproximando-nos da realidade.

\section{CONSIDERAÇÕES FINAIS}

Somos todos influenciados e formados por várias identidades. Já não temos a convicção de até que ponto somos o que somos e quem somos. José Saramago, como escultor 
da palavra, não traz no romance em estudo uma solução categórica. Aponta para uma reflexão crítica no que diz respeito à questão identitária: Que o encontro do sujeito na busca por si perpassa pelo encontro com o outro. Metaforicamente, esse outro é o duplicado, o igual ao protagonista Tertuliano Máximo Afonso. Nos induzindo a pensar que buscamos no outro o que pode ser encontrado em nós mesmos.

Entretanto, perceber semelhança com o outro, causa dores e temores ao professor de História, isto é, não há espaço harmônico para a igualdade entre duas identidades diferentes: a de Tertuliano e António Claro. Para que um dos homens iguais viva, na obra, é preciso a morte do outro, mostrando quão complexa é a existência humana. Assim, percebe-se a valia que a literatura tem na tentativa de compreensão analítica e reflexiva da inserção do homem na sociedade, imersa de incertezas e angústias.

Além disso, a obra saramaguiana em estudo destila universalidade na temática, abarcando leitores das mais diversas correntes. Levando o leitor a reflexões significativas quanto a busca constante, indispensável e inerente ao homem por afirmação identitária, para que esse possa, de modo consciente, inventar e reinventar a procura do Eu. Tal fato ocorre ao representar de forma maestra figuras e aspectos da memória e do viver coletivo, o que torna Saramago um escritor universal, traduzido, lido e compreendido nas mais diversas línguas.

José Saramago traduziu, em uma parte extensiva de suas obras, em especial em $O$ homem duplicado, um olhar apurado sobre fatos do presente, neste caso, sobre o âmbito da identidade e da alteridade. Podemos ver Maria da Paz como uma possível representação de alter ego do escritor, haja vista que a personagem conseguiu perceber o caos ao qual a vida de Tertuliano estava envolvida e, Saramago nos convida, por meio de seu olhar altamente lúcido, em suas narrativas, a observarmos o caos em que a humanidade está mergulhada.

Outro ponto a ser inferido é o da fragilidade das relações humanas. Conforme o exemplo do protagonista do enredo, na existência real, a dificuldade em se manter laços sólidos e duradouros com o semelhante é imensa. Temos medo de fundir duas vidas, pavor do futuro labiríntico e desconhecido que é conviver com o outro.

Podemos notar, também, o modo reinventado como o português abordou o tema da duplicação do homem, para além de que uma visão materialista e biológica poderia alcançar. Desta maneira, esta narrativa ficcional, nos atrai ao olhar crítico sobre a representatividade da identidade do ser humano, nos distanciando e, ao mesmo tempo, aproximando-nos da realidade.

A igualdade física que Tertuliano Máximo Afonso encontra em António Claro se opõe à diferença no que diz respeito ao modo de agir: Corpos iguais, entretanto, personalidades diferentes. O encontro dos dois é a metáfora das múltiplas identidades que o sujeito pós-moderno pode assumir. Ainda podemos dizer que a descoberta, já no fim do enredo, de que não há apenas um homem duplicado, mas o triplicado, corrobora a ideia do indivíduo multifacetado, ou seja, repleto de identidades distintas.

Por fim, o que fica, a respeito da identidade na Pós-Modernidade, é a hipótese de que é um tema em construção, à deriva das incertezas. Certos, apenas, de conviver com concepções diferentes, sem doutrinas ou verdades absolutas, mas, sim, com o cultivo de 
suposições e probabilidades. Restando-nos, por meio da literatura, a tentativa de compreender a complexidade que é o ser humano contemporâneo: No limiar da desordem e da ordem; no vazio existencial e imerso em indagações intensas, sobre o sentido de seu existir.

\section{REFERÊNCIAS}

ARNAUT, Ana Paula. José Saramago. Lisboa, Portugal: Edições 70, 2008.

BAUMAN, Zygmunt. Identidade: entrevista a Benedetto Vecchi. MEDEIROS, Carlos Alberto [tradução]. Rio de Janeiro: Zahar, 2005.

GIDDENS, Anthony. Modernidade e identidade. DENTZIEN, Plínio [tradução]. Rio de Janeiro: Zahar, 2002.

HUTCHEON, Linda. Metaficção historiográfica: O passatempo do tempo passado. In: Poética do pós-modernismo: história, teoria, fiçãa. CRUZ, Ricardo [tradução]. Rio de Janeiro: Imago Ed., 1991.

LOPES, João Marques. Saramago - Biografia. São Paulo: Leyda, 2010.

REIS, Carlos. José Saramago - O homem diante do espelho. In: ARNAUT, Ana Paula. José Saramago. Lisboa, Portugal: Edições 70, 2008.

SARAMAGO, José. O homem duplicado. São Paulo: Companhia das Letras, 2008. - A caverna. São Paulo: Companhia das Letras, 2000. . O conto da ilha desconhecida. São Paulo: Companhia das Letras, 1998.

VALVERDE, Tércia Costa. Ensaios: teoria e crítica literária. Salvador: EDUNEB; Feira de Santana: UEFS, 2014.

Recebido em: 05/06/2017

Aprovado em: 23/07/2017

Publicado em: 01/12/2017 